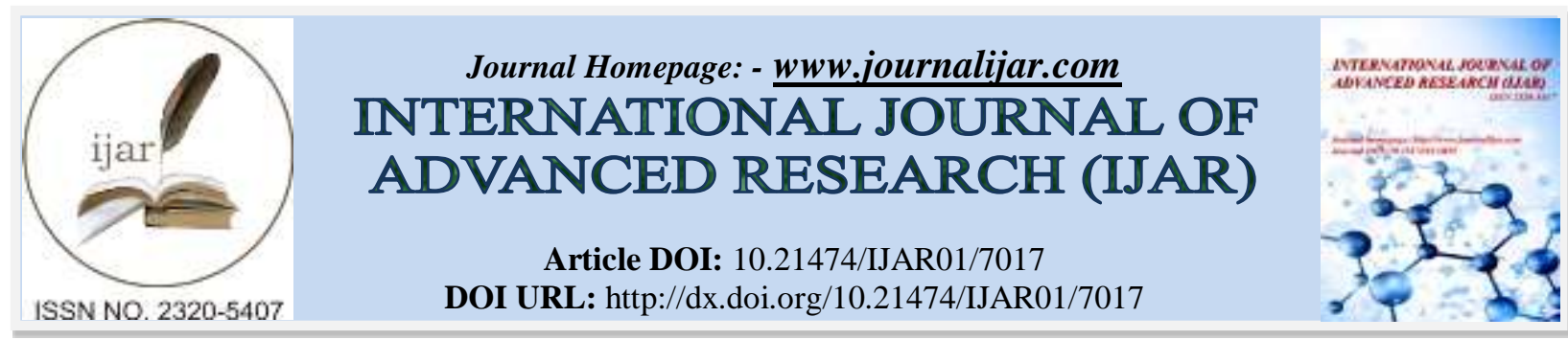

RESEARCH ARTICLE

\title{
CAN VITAMIN D SUPPLEMENTAL THERAPY IMPROVE PREGNANCY-ASSOCIATED ANEMIA? AN INTERVENTIONAL PROSPECTIVE CLINICAL TRIAL.
}

\section{Ayman A. Shedid MD ${ }^{1}$ and Amira MN Abdelrahman MD $^{2}$.}

1. Departments of Obstetrics \& Gynecology, Faculty of Medicine, Benha University.

2. Departments of Clinical Pathology, Faculty of Medicine, Benha University.

\section{Manuscript Info}

Manuscript History

Received: 02 March 2018

Final Accepted: 04 April 2018

Published: May 2018

Keywords:-

Pregnancy-induced pregnancy, Vitamin

D deficiency, Hemoglobin

concentration, Hepcidin.

\section{Abstract}

Objectives: To evaluate impact of vitamin D supplemental therapy (VD-ST) and iron ST (IST) on hemoglobin concentration (HC) in pregnant women.

Patients \& Methods: 187 women pregnant were clinically evaluated and gave blood samples at $1^{\text {st }}$ trimester for estimation of $\mathrm{HC}$ and serum $25 \mathrm{OH}-\mathrm{VD}$, ferritin concentration (FC), hepcidin (HPC) and interleukin6 (IL-6). Women were categorized according to the levels of estimated parameters into control and study groups A-D. Women of groups A and $\mathrm{C}$ received VD-ST alone, group $\mathrm{B}$ received IST alone and group D received both $\mathrm{ST}$. At delivery, $\mathrm{HC}$, extent of change and frequency of pregnancy- associated anemia (PAA) were determined.

Results: At $1^{\text {st }}$ trimester, $71.7 \%$ women were anemic and $38.5 \%$ had hypoferremia, 77\% had VD deficiency (VDD) and $59.4 \%$ had both VDD and PAA. Serum HPC and IL-6 levels in anemic women especially those had VDD were significantly higher than control women. At delivery, 35\% of control women developed PAA and mean $\mathrm{HC}$ was significantly lower than $1^{\text {st }}$ trimester $\mathrm{HC}$ with a median deficit of $4.72 \mathrm{gm} / \mathrm{dl}$ (IQR: 2.8-6.4) among studied population. Frequency of anemic women in groups B-D was decreased at delivery by $21.7 \%$, $30.8 \%$ and $30.6 \%$, respectively. Statistical analyses defined high serum HPC and IL-6 levels at $1^{\text {st }}$ trimester as specific early predictors for PAA development, but early institution of ST especially VD-ST is one of the best significant predictors for improved $\mathrm{HC}$ at time of delivery.

Conclusion: VDD, hypoferremia, higher HPC and IL-6 levels constitute a vicious circle entrapping pregnant women and inducing iron deficiency anemia at delivery. Early institution of VD-ST and IST can burst this circle and induce improvement of HC up to normal range in about $30 \%$ of women presented by PAA. Thus, early estimation of $\mathrm{HC}$ and serum VD can be used as a guide for early institution of ST.

Copy Right, IJAR, 2018,. All rights reserved.

\section{Introduction:-}

Vitamin D deficiency (VDD) is very common and prescriptions of both assay and supplementation are increasing ${ }^{(1)}$. Serum 25-hydroxy vitamin D (25OH-VD) levels in women are variable as it tends to be higher during luteal phase than follicular phase in non-pregnant and were lower in pregnant than in non-pregnant women ${ }^{(2)}$. 
Vitamin D is a significant regulator of both innate and adaptive immunity by regulating cell proliferation, differentiation and apoptosis ${ }^{(3)}$. During the first weeks of pregnancy, calcitriol is increasing by $>2-3$ fold to correspond for fetal demands ${ }^{(4)}$. During pregnancy, vitamin D receptor and regulatory metabolic enzymes are expressed in the placenta and deciduas ${ }^{(3)}$, indicating a potential critical point in the immunomodulation at the maternal-fetal interface ${ }^{(5)}$, so maternal VDD was associated with pregnancy-related disorders ${ }^{(6)}$.

Anemia affects upwards of $50 \%$ of pregnant women in developing countries and is associated with adverse outcomes for mother and child ${ }^{(7)}$. Iron is an essential micronutrient. During pregnancy, the placenta adapts by upregulating its transfer systems to maintain fetal requirements of iron at the expense of the mother's stores ${ }^{(8)}$. Iron deficiency (ID) constitutes the main cause of anemia and hemoglobin concentration (HC) below $10.5 \mathrm{~g} / \mathrm{dl}$ could be considered as true anemia ${ }^{(9)}$.

Trans-placental iron transfer involves binding transferrin-bound iron to its receptor, uptake into an endosome, acidification, release of iron through divalent metal transporter 1, efflux across the basolateral membrane through ferroportin (FPN) and oxidation to ferrous ion ${ }^{(8)}$. Acute and chronic inflammation has a major impact on iron homeostasis as it affects iron trafficking and its availability to the host ${ }^{(10)}$. Hepcidin (HPC) is a mediator of innate immunity and the master regulator of systemic iron bioavailability in humans ${ }^{(11)}$ as it regulates its intestinal absorption, tissue distribution, and macrophage iron release ${ }^{(12)}$. Hepcidin regulates extracellular iron concentration by binding to the iron exporter FPN leading to functional hypoferremia through intracellular iron sequestration ${ }^{(13)}$. Thus, elevated HPC levels especially during inflammatory conditions lead to iron-release restriction ${ }^{(14)}$ and so may interfere with trans-placental iron transfer ${ }^{(15)}$.

Supplemental therapy (ST) during pregnancy is still a matter of discrepancy; despite of improved maternal hematological indexes on routine iron supplemental therapy (IST) during pregnancy, its clinical significance for both pregnant women and infants remains unclear ${ }^{(16)}$. Moreover, high intake of heme iron is associated with increased risk of gestational diabetes ${ }^{(17)}$ and glucose intolerance-related outcome was similar for selective or routine IST ${ }^{(18)}$. Concerning VD-ST, the current evidence base could not allow definite conclusions regarding the optimal maternal circulating concentration of $25 \mathrm{OH}-\mathrm{VD}$ during pregnancy, and how this might best be achieved ${ }^{(19)}$ and VDST during pregnancy was associated with increased its circulating levels, birth weight, and length, but was not associated with other outcomes ${ }^{(20)}$.

\section{Hypothesis:-}

Pathogenesis of pregnancy-associated anemia (PAA) is multi-factorial and the response to IST is either unpredicted or inefficient. The current study hypothesizes that VDD may underlay the development of PAA or the weak response to IST.

\section{Objectives:-}

The current study targets to evaluate the impact of vitamin D and iron supplemental therapy on hemoglobin concentration in pregnant women at time of delivery

\section{Design:-}

Prospective observational clinical study

\section{Setting:-}

Benha University Hospitals

\section{Patients \& Methods:-}

The study protocol was approved by the Local Ethical Committee and all enrolled women signed a written fullyinformed consent to participate in the study. The study was conducted at departments of Obstetrics \& Gynecology and Clinical Pathology, Benha University Hospitals. To exclude the seasonal variations of VD levels, all women attended the antenatal care unit at Benha University Hospital during their $1^{\text {st }}$ trimester since March $21^{\text {st }}$ till June $21^{\text {st }}$ each year for three years starting at 2015 were eligible to clinical evaluation and were asked to attend the clinic fasting on the next day to give blood samples for investigations. At time of delivery, another blood sample was obtained for re-determination of HC. Exclusion criteria included presence of multiple pregnancy, fetal congenital anomalies, current DM or essential hypertension, obesity-inducing endocrinopathy, evident manifestations of hypo- 
parathyroidism, thyrotocixosis, renal or hepatic diseases and women gave birth outside the hospital were also excluded from the study.

Vitamin D sufficiency status was defined according to $25-\mathrm{OHD}$ concentration as follows: $\geq 75 \mathrm{nmol} / \mathrm{L}$ sufficient level, $50-75 \mathrm{nmol} / \mathrm{L}$ insufficient level and $<50 \mathrm{nmol} / \mathrm{L}$ deficient level. Vitamin $\mathrm{D}$ deficiency was categorized as mild, moderate and severe if 25-OHD concentration was $25-50 \mathrm{nmol} / \mathrm{L}, 12.5-25 \mathrm{nmol} / \mathrm{L}$ and $<12.5 \mathrm{nmol} / \mathrm{L}$, respectively ${ }^{(21)}$. PAA was defined as $\mathrm{Hb}$ conc. of $<11 \mathrm{gm} / \mathrm{dl}$ either at $1^{\text {st }}$ trimester (T1) or at delivery (T2). Iron deficiency (ID) was diagnosed if serum ferritin was $<15 \mathrm{ng} / \mathrm{ml}^{(22)}$.

\section{Investigations:-}

Under complete aseptic conditions, $5 \mathrm{ml}$ blood samples were withdrawn from the antecubital vein during $1^{\text {st }}$ trimester for:

- $\quad$ Routine investigations included estimation of HC and fasting blood glucose.

- A part of blood sample was collected in a plane tube, till clotted and then was centrifuged at $3000 \mathrm{rpm}$ for 10 min. Serum was removed put in pyrogen-free Eppendorf tubes and stored at $-70^{\circ} \mathrm{C}$ until ELISA assayed for serum levels of 25OH-VD, using an ELISA kit from Cayman Chemical, Ann Arbor, MI, USA ${ }^{(23)}$, ferritin concentration (FC), using an ELISA kit from Eurogenetics UK ${ }^{(24)}$, hepcidin using ELISA kit from Quantikine r\&d systems Inc. Minneapolis MN USA ${ }^{(25)}$ and IL-6 using ELISA kit from Pelikine ${ }^{\mathrm{TM}}$ Inc., Concord, USA ${ }^{(26)}$.

\section{Study Grouping:-}

- Control group included women with HC>11 gm/dl, 25OH-VD $\geq 75 \mathrm{nmol} / \mathrm{L}$ and $\mathrm{FC} \geq 15 \mathrm{ng} / \mathrm{ml}$.

- Study groups:

- Group A: included women with HC>11 gm/dl, $25 \mathrm{OH}-\mathrm{VD}<75 \mathrm{nmol} / \mathrm{L}$ and FC $\geq 15 \mathrm{ng} / \mathrm{ml}$.

- Group B: included women with HC $<11 \mathrm{gm} / \mathrm{dl}, 25 \mathrm{OH}-\mathrm{VD} \geq 75 \mathrm{nmol} / \mathrm{L}$, irrespective of FC.

- Group C: included women with HC<11 gm/dl, 25OH-VD $<75 \mathrm{nmol} / \mathrm{L}$ and FC $\geq 15 \mathrm{ng} / \mathrm{ml}$.

- Group D: included women with HC<11 gm/dl, 25OH-VD<75 nmol/L and FC $<15 \mathrm{ng} / \mathrm{ml}$.

\section{Study Design \& Medications:-}

- Women of groups A and C received only vitamin D3 ST according to Grant et al. ${ }^{(27)}$ as a daily oral dose of $400 \mathrm{IU}$ to be taken as 4 drops daily with mail (Vidrop, Oral solution, Medical Union Pharmaceuticals, Abu Sultan, Ismailia, Egypt, provided as $100 \mathrm{IU} /$ drop). Vitamin D supplementation started since $1^{\text {st }}$ antenatal visit after giving blood sample and assuring insufficieny-deficiency till delivery.

- Women of group B received IST as a daily oral ferrous fumarate $350 \mathrm{mg}$ caps (HAEMOTON cap; containing ferrous fumarate $350 \mathrm{mg}$, vitamin $\mathrm{B}_{12} 7.5 \mu \mathrm{g}$, folic Acid $2 \mathrm{mg}$, ascorbic acid $50 \mathrm{mg}$ and other vitamins; Glaxo Smith Kline Co., Egypt).

- Women of group D received both IST and VD-ST, while control women received no supplemental therapy

\section{Study outcome:-}

- Determination of frequencies of PAA, ID, ID anemia (IDA) and VDD.

- $\quad$ Evaluation of the effect of VD-ST on the severity of PAA and if this effect can be modulated by combination with IST or not.

- $\quad$ Trying to determine the association between studied parameters and early prediction of the oncoming $\mathrm{HC}$ at time of delivery.

\section{Statistical analysis:-}

Obtained data were presented as mean \pm SD, numbers and percentages. Results were analyzed using Student and paired t-test and Chi-square test $\left(\mathrm{X}^{2}\right.$ test). Data were analyzed using Regression analysis (Stepwise Method) to define the significant predictors for $\mathrm{HC}$ and its extent of change at time of delivery in relation to $1^{\text {st }}$ trimester $\mathrm{HC}$ and for development of PAA at time of delivery in pregnant women. ROC curve analysis for laboratory parameters estimated at $1^{\text {st }}$ trimester for prediction of development of PAA at time of delivery and for the appropriate supplemental therapy for PAA minimization or prevention. Statistical analysis was conducted using the IBM SPSS (Version 23, 2015) for Windows statistical package. $\mathrm{P}$ value $<0.05$ was considered statistically significant.

\section{Results:-}

The study included 217 pregnant women eligible for evaluation; 30 were excluded and 187 were enrolled in the study. According to estimated serum $25 \mathrm{OH}-\mathrm{VD}$ levels, 43 women had sufficient, 49 women had insufficient, 44 
women had mild VDD and 51 women had moderate VDD. As regards PAA, 53 women had no anemia, while 134 women had PAA. For grouping, 20 women were considered as control women, and 33, 23, 39 and 72 women were included in study groups A-D, respectively. Enrolment data of studied women as shown in table 1 showed nonsignificant difference between groups.

Table 1:-Patients' enrolment data

\begin{tabular}{|c|c|c|c|c|c|c|}
\hline \multirow{2}{*}{\multicolumn{2}{|c|}{ Data }} & \multirow{2}{*}{$\begin{array}{l}\text { Control } \\
\text { group }\end{array}$} & \multicolumn{4}{|c|}{ Study groups } \\
\hline & & & $\mathrm{A}$ & B & $\mathrm{C}$ & $\mathrm{D}$ \\
\hline \multicolumn{2}{|l|}{ Number } & $20(10.7 \%)$ & $33(17.7 \%)$ & $23(12.3 \%)$ & $39(20.9 \%)$ & $72(38.4 \%)$ \\
\hline \multicolumn{2}{|l|}{ Age (years) } & $27.7 \pm 2.6$ & $27.6 \pm 2.7$ & $27.9 \pm 2.3$ & $27.4 \pm 2.5$ & $28.2 \pm 2.7$ \\
\hline \multirow{3}{*}{$\begin{array}{l}\text { Body mass index } \\
\text { data }\end{array}$} & Weight (kg) & $77.3 \pm 4.8$ & $79.8 \pm 3.4$ & $74.8 \pm 3.9$ & $76.2 \pm 4.4$ & $79.4 \pm 7.9$ \\
\hline & Height $(\mathrm{cm})$ & $170.4 \pm 3.3$ & $169.8 \pm 2.7$ & $167.1 \pm 3.1$ & $169.8 \pm 2.7$ & $168.3 \pm 3.2$ \\
\hline & BMI $\left(\mathrm{kg} / \mathrm{m}^{2}\right)$ & $26.5 \pm 3.4$ & $27.2 \pm 4.1$ & $27.5 \pm 3.2$ & $27.3 \pm 2.3$ & $28 \pm 2.7$ \\
\hline \multirow[t]{2}{*}{ Gravidity } & Primi & $6(30 \%)$ & $12(36.4 \%)$ & $6(26.1 \%)$ & $11(28.2 \%)$ & $23(31.9 \%)$ \\
\hline & Multi & $14(70 \%)$ & $21(63.6 \%)$ & $17(73.9 \%)$ & $28(71.8 \%)$ & $39(68.1 \%)$ \\
\hline \multirow{2}{*}{$\begin{array}{l}\text { Blood pressure } \\
(\mathrm{mmHg})\end{array}$} & Systolic & $113.5 \pm 3.4$ & $114.8 \pm 3.1$ & $114.5 \pm 3.9$ & $114.7 \pm 3.2$ & $114.3 \pm 9.8$ \\
\hline & Diastolic & $72.3 \pm 3.5$ & $72.5 \pm 3.4$ & $72.2 \pm 2.9$ & $71.8 \pm 3.2$ & $71.9 \pm 4.5$ \\
\hline \multicolumn{2}{|c|}{ Fasting blood glucose $(\mathrm{mg} / \mathrm{dl})$} & $97.1 \pm 3.7$ & $96.4 \pm 3.9$ & $98.2 \pm 3.3$ & $96.6 \pm 3.8$ & $99.4 \pm 5$ \\
\hline
\end{tabular}

Data are presented as mean \pm SD \& numbers; BMI: Body mass index

Mean initial HC was significantly lower in groups B-D compared to groups A and B. Mean estimated FC levels were significantly lower in women of group D compared to women of all other groups and in women of group C compared to those of group A. Estimated $25 \mathrm{OH}-\mathrm{VD}$ levels were significantly lower in women of groups $\mathrm{D}$ compared to women of other groups and in women of groups $\mathrm{A}$ and $\mathrm{C}$ compared to women of control group and group B, (Table 2).

Table 2:-PAI and VDD data of studied patients

\begin{tabular}{|c|c|c|c|c|c|c|c|}
\hline \multirow[t]{2}{*}{ Parameters } & \multirow{2}{*}{\multicolumn{2}{|c|}{ Data }} & \multirow{2}{*}{$\begin{array}{l}\text { Control } \\
(n=20)\end{array}$} & \multicolumn{4}{|c|}{ Study groups } \\
\hline & & & & $A(n=33)$ & $B(n=23)$ & $C(n=39)$ & $\mathrm{D}(\mathrm{n}=72)$ \\
\hline \multirow{3}{*}{$\begin{array}{l}\mathrm{HC} \\
(\mathrm{mg} / \mathrm{dl})\end{array}$} & \multirow{2}{*}{$\begin{array}{l}\text { PAA } \\
\text { frequency }\end{array}$} & $>11$ & $20(100 \%)$ & $33(100 \%)$ & 0 & 0 & 0 \\
\hline & & $<11$ & 0 & 0 & $23(100 \%)$ & $39(100 \%)$ & $72(100 \%)$ \\
\hline & \multicolumn{2}{|l|}{ Mean $( \pm S D)$} & $12.3 \pm 0.6$ & $12.1 \pm 0.5$ & $10.7 \pm 0.2 * \dagger$ & $10.8 \pm 0.14^{* \dagger}$ & $10.7 \pm 0.2 * \dagger$ \\
\hline \multirow[t]{3}{*}{$\mathrm{FC}(\mathrm{ng} / \mathrm{ml})$} & \multirow{2}{*}{$\begin{array}{l}\text { IDA } \\
\text { frequency }\end{array}$} & $>15$ & $20(100 \%)$ & $33(100 \%)$ & $23(100 \%)$ & $39(100 \%)$ & 0 \\
\hline & & $<15$ & 0 & 0 & 0 & 0 & $72(100 \%)$ \\
\hline & \multicolumn{2}{|l|}{ Mean $( \pm \mathrm{SD})$} & $17 \pm 1.2$ & $17 \pm 1.33$ & $16.9 \pm 1.27$ & $16.2 \pm 0.8 \dagger$ & $13.1 \pm 1.2 *++1$ \\
\hline \multirow{5}{*}{$\begin{array}{l}\text { Serum } \\
25 \mathrm{OH}-\mathrm{VD} \\
(\mathrm{nmol} / \mathrm{l})\end{array}$} & \multirow{4}{*}{$\begin{array}{l}\text { Frequency } \\
\text { according } \\
\text { to } \\
\text { sufficiency }\end{array}$} & Sufficient & $20(100 \%)$ & 0 & $23(100 \%)$ & 0 & 0 \\
\hline & & Insufficient & 0 & $14(42.4 \%)$ & 0 & $26(66.7 \%)$ & $9(12.5 \%)$ \\
\hline & & Mild VDD & 0 & $15(45.5 \%)$ & 0 & $8(20.5 \%)$ & $21(29.2 \%)$ \\
\hline & & $\begin{array}{l}\text { Moderate } \\
\text { VDD }\end{array}$ & 0 & $4(12.1 \%)$ & 0 & $5(12.8 \%)$ & $42(58.3 \%)$ \\
\hline & \multicolumn{2}{|l|}{ Mean $( \pm S D)$} & $77.9 \pm 1.2$ & $53.8 \pm 18.4 *+$ & $76.7 \pm 1$ & $54 \pm 18.5^{*}+$ & $31.8 \pm 13.1 *++1$ \\
\hline
\end{tabular}

HC: Hemoglobin concentration; FC: Ferritin concentration; 25OH-VD: 25 hydroxy vitamin D; PAA: Pregnancyassociated anemia; IDA: Iron deficieny anemia; VDD: Vitamin D deficiency; *: significant difference versus control group; $\uparrow$ : significant difference versus Group A; + : significant difference versus Group B; $q$ : significant difference versus Group C

Women of groups $\mathrm{C}$ and D had significantly $(\mathrm{p}<0.05)$ higher serum HPC levels compared to women of control and study groups A and B. Women of group A had significantly $(\mathrm{p}<0.05)$ higher, while women of group B had nonsignificantly $(\mathrm{p}>0.05)$ higher serum HPC levels compared to control women. Serum IL-6 levels were significantly $(\mathrm{p}<0.05)$ higher in women of groups A, C and D, and non-significantly $(\mathrm{p}>0.05)$ higher in women of group B compared control women. Moreover, estimated serum IL-6 levels were significantly $(\mathrm{p}<0.05)$ higher in women of study groups A-D compared to group B and in women of group D than those of group A (Table 3). 
Table 3:-Serum Hepcidin and IL-6 levels estimated in studied patients at the $1^{\text {st }}$ trimester

\begin{tabular}{|l|c|c|c|c|c|}
\hline Parameters & \multirow{2}{*}{$\begin{array}{c}\text { Control } \\
(\mathrm{n}=20)\end{array}$} & \multicolumn{4}{|c|}{ Study groups } \\
\cline { 3 - 6 } & $17.5 \pm 3.7$ & $25.5 \pm 8.6^{*}$ & $20.5 \pm 4.5$ & $\mathrm{C}(\mathrm{n}=39)$ & $\mathrm{D}(\mathrm{n}=72)$ \\
\hline HPC $(\mathrm{ng} / \mathrm{ml})$ & $22.5 \pm 10 *+1$ & $39.9 \pm 14.9^{*}$ & $26.6 \pm 10.6 \dagger$ & $47.4 \pm 12.9 * \dagger$ & $34.7 \pm 13.5^{*}+\dagger$ \\
\hline IL-6 $(\mathrm{ng} / \mathrm{ml})$ & $22.5 \pm 10.1$ & $\mathrm{~B}(\mathrm{n}=23)$ & $48.7 \pm 13.5^{*}+\dagger$ \\
\hline
\end{tabular}

Data are presented as mean \pm SD; HPC: hepcidin; IL-6: Interleukin-6; *: significant difference versus control group; $\dagger$ : significant difference versus Group A; $\uparrow$ : significant difference versus Group B

All women showed decreased $\mathrm{HC}$ at time of delivery that was significantly $(\mathrm{p}<0.05)$ lower than at $1^{\text {st }}$ trimester $\mathrm{HC}$ in women of control group and study groups $\mathrm{A}$ and $\mathrm{B}$, but was non-significant ( $>0.05)$ in women of groups $\mathrm{C}$ and D. Moreover, the frequency of PAA increased in control and study group A by $35 \%$ and $27.3 \%$ with nonsignificantly ( $p>0.05)$ higher frequency and extent of deficit among women of control group than women of study group A. On contrary, the frequency of PAA was decreased by $21.7 \%, 30.8 \%$ and $30.6 \%$ among women of group B$\mathrm{D}$, respectively with non-significantly $(\mathrm{p}>0.05)$ higher frequency and extent of deficit among women of group $\mathrm{B}$ than women of groups $\mathrm{C}$ and $\mathrm{D}$ (Table 4).

Table 4:-HC estimated at time of delivery and its extent of change in relation to concentration estimated at $1^{\text {st }}$ trimester

\begin{tabular}{|c|c|c|c|c|c|c|c|c|}
\hline \multicolumn{2}{|r|}{ Parameter } & \multicolumn{4}{|c|}{$\mathrm{HC}$} & \multicolumn{3}{|c|}{ Frequency of PAA } \\
\hline Group & Time & $1^{\text {st }}$ trimester & Delivery & $\mathrm{P}$ value & Deficit & $1^{\text {st }}$ trimester & Delivery & Change \\
\hline \multicolumn{2}{|c|}{ Control $(n=20)$} & $12.3 \pm 0.6$ & $11.5 \pm 0.8$ & 0.001 & $6.9 \pm 3.7$ & 0 & $35 \%$ & $\uparrow$ by $35 \%$ \\
\hline \multirow[t]{4}{*}{ Study } & $A(n=33)$ & $12.1 \pm 0.5$ & $11.5 \pm 0.6$ & 0.011 & $4.54 \pm 2.2$ & 0 & $27.3 \%$ & $\uparrow$ by $27.3 \%$ \\
\hline & $B(n=23)$ & $10.7 \pm 0.2$ & $10.4 \pm 0.6$ & 0.026 & $2.78 \pm 5.6$ & $100 \%$ & $78.3 \%$ & $\downarrow$ by $21.7 \%$ \\
\hline & $C(n=39)$ & $10.8 \pm 0.1$ & $10.6 \pm 0.7$ & 0.218 & $1.23 \pm 6.1$ & $100 \%$ & $69.2 \%$ & $\downarrow$ by $30.8 \%$ \\
\hline & $\mathrm{D}(\mathrm{n}=72)$ & $10.7 \pm 0.2$ & $10.6 \pm 0.8$ & 0.094 & $1.34 \pm 6.6$ & $100 \%$ & $69.4 \%$ & $\downarrow$ by $30.6 \%$ \\
\hline
\end{tabular}

Regression analysis defined presence of VDD manifested as low serum 25OH-VD level and high HPC serum, estimated at $1^{\text {st }}$ trimester, as the significant negative predictor for low $\mathrm{HC}$ at time of delivery. Moreover, Regression analysis defined the early initiation of VD-RT alone or in combination with IST as positive predictors for maintained or improved $\mathrm{HC}$ at time of delivery. For prediction of $\mathrm{HC}$ deficit at time of delivery, Regression analysis defined high serum 25OH-VD as positive and high serum IL-6 as negative significant predictors for small HC deficit and early initiation of VD-ST as a positive significant predictor for small HC deficit. Also, regression analysis defined high serum IL-6 estimated at the $1^{\text {st }}$ trimester as a positive, while high serum $25 \mathrm{OH}-\mathrm{VD}$ and early initiation of VD-ST alone or in combination with IST as negative significant predictors of persistence or development of PAA at time of delivery, (Table 5).

Table 5:-Regression analysis for predictors of HC status at time of delivery in studied population

\begin{tabular}{|l|l|c|c|}
\hline \multirow{4}{*}{ HC } & At booking parameters & Standardized coefficient & $\mathrm{p}$ \\
\cline { 2 - 4 } & HPC & -3.699 & 0.0009 \\
\cline { 2 - 4 } & VDD & -7.988 & 0.0003 \\
\cline { 2 - 4 } & Combined VD-ST \& IST & 5.554 & 0.0007 \\
\cline { 2 - 4 } & VD-ST & 4.081 & 0.0005 \\
\hline \multirow{4}{*}{$\begin{array}{l}\text { HC deficit } \\
\text { Persistence }\end{array}$} & 25OH-VD & 0.621 & 0.0004 \\
\cline { 2 - 4 } & VD-ST & 0.453 & 0.0007 \\
\cline { 2 - 4 } & IL-6 & -0.199 & 0.011 \\
\cline { 2 - 4 } & 25OH-VD & -0.804 & 0.0001 \\
\cline { 2 - 4 } & VD-ST & -0.531 & 0.008 \\
\cline { 2 - 4 } & IL-6 & 0.200 & 0.009 \\
\cline { 2 - 4 } & Combined VD-ST \& IST & -0.216 & 2507 \\
\hline
\end{tabular}

VDD: vitamin D deficiency; VD-ST: VD supplemental therapy; IST: Iron supplemental therapy; 25OH-VD: 25hydroxy vitamin D; IL-6: Interleukin 6

The ROC curve analysis defined low serum 25OH-VD and FC as sensitive and high serum HPC and IL-6 levels as specific early predictor for development of PAA at time of delivery (Fig. 1). Moreover, ROC curve analysis defined 
early initiation of VD-ST as the best specific predictor for correction or avoidance of development of PAA (Table 6, Fig. 2).

Table 6:-ROC curve analysis for predictors of PAA at time of delivery in studied population

\begin{tabular}{|l|c|c|c|c|c|c|c|c|c|}
\hline \multicolumn{4}{|c|}{ Parameters estimated at $1^{\text {st }}$ trimester } & \multicolumn{5}{c|}{ Supplemental therapy } \\
\hline Parameter & AUC & SE & P & $95 \%$ CI & Line & AUC & SE & P & $95 \%$ CI \\
\hline 25OH-VD & 0.267 & 0.036 & 0.0002 & $0.196-0.339$ & VD & 0.629 & 0.042 & 0.003 & $0.547-0.71$ \\
\hline FC & 0.327 & 0.041 & 0.0006 & $0.246-0.407$ & Iron & 0.506 & 0.043 & $>0.05$ & $0.421-0.59$ \\
\hline HPC & 0.635 & 0.043 & 0.002 & $0.550-0.719$ & Both & 0.580 & 0.042 & $>0.05$ & $0.498-0.663$ \\
\hline IL-6 & 0.614 & 0.043 & 0.009 & $0.528-0.698$ & & & & & \\
\hline
\end{tabular}

AUC: Area under curve; SE: Standard error; CI: confidence interval; 25OH-VD: 25 hydroxy vitamin D; FC: Ferritin concentration; HPC: Hepcidin; IL-6: Interleukin-6; PAA: Pregnancy-associated anemia; IDA: Iron deficiency anemia

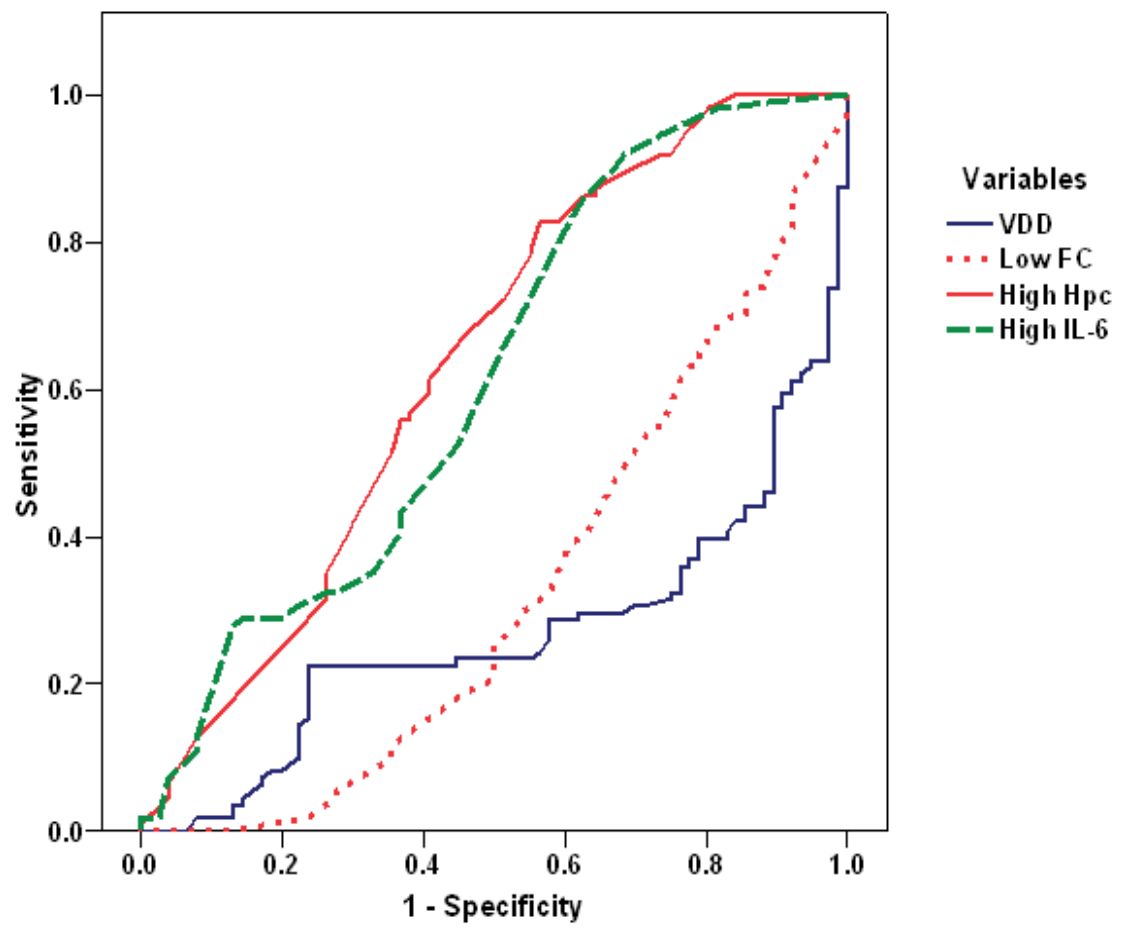

Fig. 1:-ROC curve analysis of laboratory parameters estimated at the $1^{\text {st }}$ trimester for prediction of PAA at time of delivery 


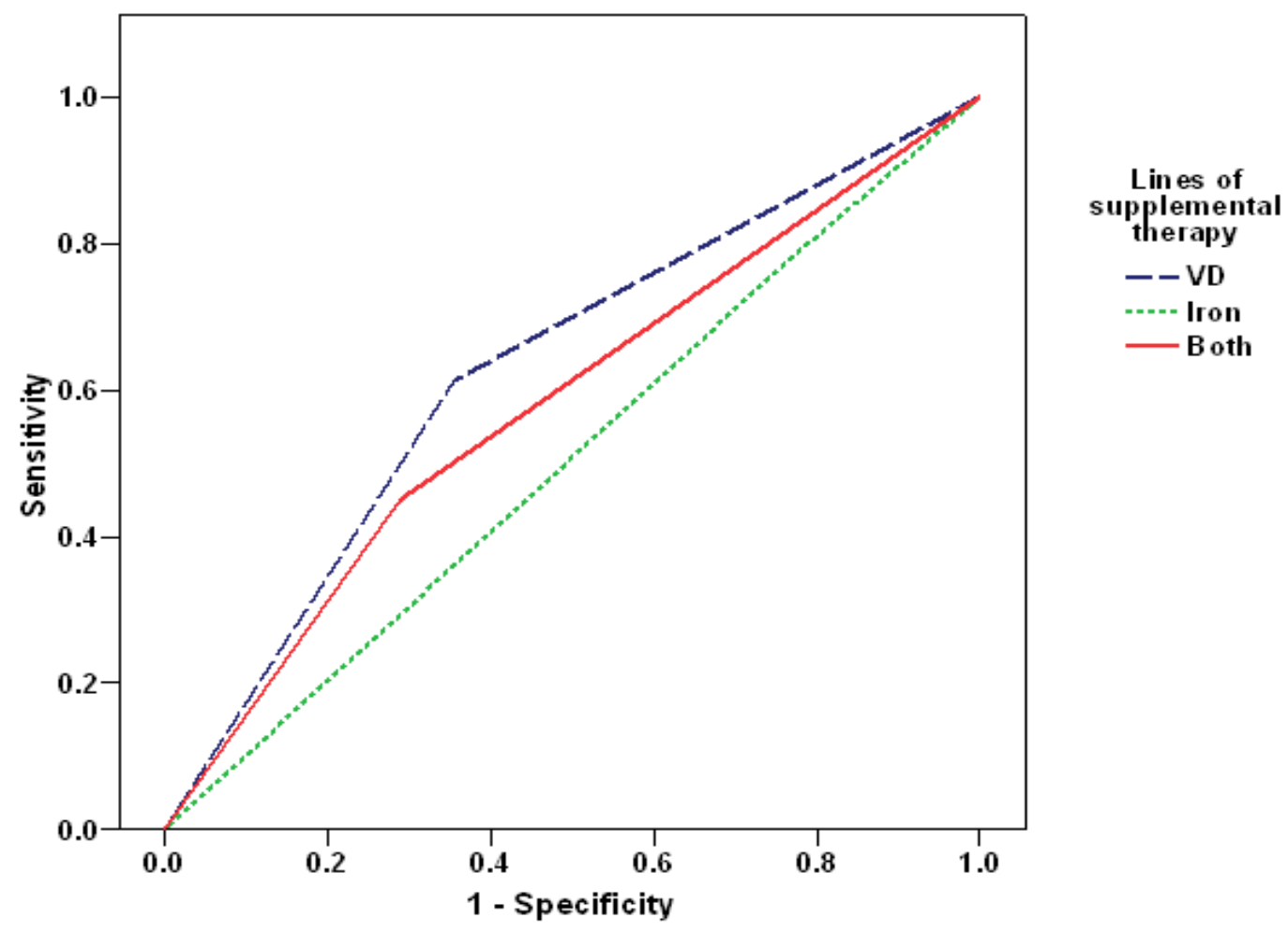

Fig. 2:-ROC curve analysis of lines of supplemental therapies for prevention or minimization of development of PAA at time of delivery

\section{Discussion:-}

At the $1^{\text {st }}$ trimester, $71.7 \%$ women were anemic and $38.5 \%$ had hypoferremia indicating decreased iron stores, such frequency is in line with Breymann ${ }^{(9)}$ who documented that worldwide prevalence of IDA ranged between $20-80 \%$ and the majority is females. Also, Abbas et al. ${ }^{(28)}$ detected frequencies of anemia, hypoferremia and IDA of $57.7 \%$, $21.3 \%$ and $12.1 \%$ among Sudanese pregnant women. Moreover, Milman et al. ${ }^{(29)}$ reported that about $20-35 \%$ of European women of reproductive age had sufficient iron stores to complete a pregnancy without developing ID or IDA without receiving iron supplements

The obtained results illustrated the deleterious effect of pregnancy on maternal iron homeostasis as manifested by the reported frequency of anemic women at time of delivery among control women who were not anemic and had sufficient VD and FC at the $1^{\text {st }}$ trimester and the mean HC estimated at time of delivery was significantly lower than that estimated at $1^{\text {st }}$ trimester with a median deficit of $4.72 \mathrm{gm} / \mathrm{dl}$ (IQR: 2.8-6.4) among studied population.

These results go in hand with Milman et al. ${ }^{(29)}$ who suggested that between 32-39 wk GA, prevalence of ID and IDA was 28-85\% and 21-35\%, respectively, among European women and Bah et al. ${ }^{(30)}$ who found the prevalence of anemia increased from $34.6 \%$ at $14 \mathrm{wk}$ to $50 \%$ at $20 \mathrm{wk}$ GA. Recently, Ahmed et al. ${ }^{(31)}$ reported an overall frequency of anemia, ID and IDA of $34.7 \%, 27 \%$ and $13.4 \%$ of their series of pregnant women.

At the $1^{\text {st }}$ trimester, 77\% of the studied population had VDD, 111 women had both VDD and PAA, 33 women had VDD with normal HC and 23 were anemic without VDD. Thus, a relationship between both VDD and PAA was evident in $59.4 \%$ of studied population.

Multiple clinical studies detected a similar association where Michalski et al. ${ }^{(32)}$ found low vitamin D status may be linked to reduced HC in pregnant women. Also, Yuan et al. ${ }^{(33)}$ reported that maternal serum $250 H-V D<50.0$ $\mathrm{nmol} / \mathrm{L}$ may be a risk factor for gestational anemia, and it should be monitored for the high-risk pregnant women. Recently, Al-Ajlan et al. ${ }^{(34)}$ detected VDD $(<50 \mathrm{nmol} / \mathrm{l})$ in about $82.5 \%$ of 515 pregnant Saudi women during the 
$1^{\text {st }}$ trimester. Also, Krieger et al. ${ }^{(35)}$ detected $53.4 \%$ prevalence of VDD in their sample of pregnant women in Switzerland and Wheeler et al. ${ }^{(36)}$ documented that VDD in women in New Zealand is very common during pregnancy and lactation and accounted for a prevalence of $65 \%$.

The results of the current study showed significantly higher serum levels of HPC and IL-6 in anemic women especially those had VDD. In support of the association between VDD and inflammatory processes manifested as high serum levels of pro-inflammatory cytokines, Akoh et al. ${ }^{(37)}$ found maternal serum 1,25-(OH) 2 VD was significantly inversely associated with serum TNF- $\alpha$ especially at delivery and suggested that maternal VDD may increase risk of infection across gestation.

Statistical analyses defined high serum HPC and IL-6 levels at $1^{\text {st }}$ trimester as specific early predictors for development of PAA at time of delivery. These findings are in accordance with Bah et al. ${ }^{(30)}$ who found HPC was superior to hemoglobin and sTfR as an indicator of ID with high $\mathrm{AUC}^{\mathrm{ROC}}$ values for HPC to detect ID since the $14^{\text {th }}$ wk GA. Cutone et al. ${ }^{(38)}$, (2017) explored the relationship between anemia and inflammation and found increased IL-6 and IL-1 $\beta$ induced up-regulation of cytosolic ferritin and down-regulation of FPN leading to intracellular iron overload that induces higher host susceptibility to infections and ID with subsequent anemia. Also, Rosa et al. ${ }^{(39)}$ attributed the curative effect of bovine lactoferrin on anemia of inflammation to its anti-inflammatory activity against IL-6 with subsequent up-regulation of FPN and transferrin receptor 1, while down-regulation of ferritin leading to inhibition of intracellular iron overload and so increasing iron availability for erythropoithesis.

Despite of the still active discrepancy concerning VD-ST and/or IST during pregnancy, supplemental therapy in the form of VD-ST alone, IST alone or combination fructified the outcome of pregnant women of groups B-D, respectively as manifested by the frequency of women who showed increased $\mathrm{HC}$ at time of delivery, despite being anemic at $1^{\text {st }}$ trimester. Furthermore, statistical analyses defined early institution of ST especially concerning VD-ST is one of the best significant predictors for improved $\mathrm{HC}$ at time of delivery.

In support of the role of ST, the frequency of PAA reported at time of delivery in control women who had within normal range $\mathrm{HC}$ and serum VD and FC at $1^{\text {st }}$ trimester and in support of the combined ST, the frequency of PAA at time of delivery in women of group A and the decreased frequency in group D.

In line with the reported outcome, Krieger et al. ${ }^{(35)}$ documented that VD supplement intake was the most actionable determinant of VD status at the $3^{\text {rd }}$ trimester and in neonatal cord blood, suggesting that VD-ST during pregnancy should receive more attention in clinical practice. Also, Wheeler et al. ${ }^{(36)}$ recommended $1^{\text {st }}$ trimester maternal VD screening and targeted supplementation for those "at risk".

The reported beneficial effect of VD-ST could be attributed to multiple mechanisms illustrating how VD can control iron homeostasis; where it was supposed that VDD induces local calcitriol production by bone marrow with concomitant increased membrane calcium permeability with susbsequent decline of erythropoiesis ${ }^{(40)}$. Later on these theoretical suggestions were approved experimentally to occur at mRNA and protein levels ${ }^{(41,42)}$. Another supposition was that VDD induces hyperparathyroidism with subsequent increased proliferation of erythroid progenitor cells ${ }^{(43)}$. Clinically, multiple suggestions were provided for the association between VDD and anemia as Thomas et al. ${ }^{(44)}$ attributed the effect of VDD on HC in pregnant women to both a direct effect and an indirect effect mediated by erythropoietin. Interestingly, Azizi-Soleiman et al. ${ }^{(45)}$ detected a positive relationship between iron status and VD and attributed it a possible reciprocal relation where VDD is associated with higher HPC level causing reduction of iron release which in turn induced reduction of activation of hydroxylases that yield calcitriol, so constituting a vicious circle. Recently, Liu et al. ${ }^{(46)}$ experimentally in antenatal lipopolysaccharide-treated rats found VD increased the methylation percentage of the VD-response element in IFN- $\gamma$-promoter region and suppressed its LPS-induced and reported clinically an association between maternal VD exposure during pregnancy and neonatal IFN- $\gamma$ levels, so suggested that supplementation of VD could suppress IFN- $\gamma$ production with its hazardous maternal, fetal and neonatal effects.

\section{Conclusion:-}

Vitamin D deficiency, hypoferremia, higher HPC and IL-6 constitute a vicious circle entrapping the pregnant women and inducing iron deficiency anemia at time of delivery. Early institution of supplemental therapy of vitamin $\mathrm{D}$ and iron can burst this circle and induce improvement of $\mathrm{HC}$ up to the normal range in about $30 \%$ of women presented by PAA. Thus, early estimation of HC and serum VD can be used as a guide for early institution of ST. 


\section{References:-}

1. Cesareo R, Attanasio R, Caputo M, Castello R, Chiodini I, Falchetti A, Guglielmi R, Papini E, Santonati A, Scillitani A, Toscano V, Triggiani V, Vescini F, Zini M; AME and Italian AACE Chapter: Italian Association of Clinical Endocrinologists (AME) and Italian Chapter of the American Association of Clinical Endocrinologists (AACE) Position Statement: Clinical Management of Vitamin D Deficiency in Adults. Nutrients. 2018 Apr 27;10(5).

2. Agudelo-Zapata Y, Maldonado-Acosta LM, Sandoval-Alzate HF, Poveda NE, Garcés MF, Cortés-Vásquez JA, Linares-Vaca AF, Mancera-Rodríguez CA, Perea-Ariza SA, Ramírez-Iriarte KY, Castro-Saldarriaga CA, ArteagaDiaz JM, Franco-Vega R, Angel-Muller E, Parada-Baños AJ, Caminos JE: Serum 25-hydroxyvitamin D levels throughout pregnancy: a longitudinal study in healthy and preeclamptic pregnant women. Endocr Connect. 2018 Apr 17. pii: EC-18-0055. doi: 10.1530/EC-18-0055. [Epub ahead of print]

3. Ji JL, Muyayalo KP, Zhang YH, Hu XH, Liao AH: Immunological function of vitamin D during human pregnancy. Am J Reprod Immunol. 2017; 78(2).

4. Olmos-Ortiz A, Avila E, Durand-Carbajal M, Díaz L: Regulation of calcitriol biosynthesis and activity: focus on gestational vitamin D deficiency and adverse pregnancy outcomes. Nutrients. 2015; 7(1):443-80.

5. Tamblyn JA, Hewison M, Wagner CL, Bulmer JN, Kilby MD: Immunological role of vitamin D at the maternal-fetal interface. J Endocrinol. 2015; 224(3):R107-21.

6. Karras SN, Wagner CL, Castracane VD: Understanding vitamin D metabolism in pregnancy: From physiology to pathophysiology and clinical outcomes. Metabolism. 2017 Oct 21. pii: S0026-0495(17)30275-5. doi: 10.1016/j.metabol.2017.10.001. [Epub ahead of print]

7. Page CM, Patel A, Hibberd PL: Does smoke from biomass fuel contribute to anemia in pregnant women in Nagpur, India? A cross-sectional study. PLoS One. 2015; 10(5):e0127890.

8. McArdle HJ, Gambling L, Kennedy C: Iron deficiency during pregnancy: the consequences for placental function and fetal outcome. Proc Nutr Soc. 2014; 73(1):9-15.

9. Breymann C: Iron Deficiency Anemia in Pregnancy. Semin Hematol. 2015; 52(4):339-47.

10. Ross AC: Impact of chronic and acute inflammation on extra- and intracellular iron homeostasis. Am J Clin Nutr. 2017;106(Suppl 6):1581S-1587S.

11. Koenig MD, Tussing-Humphreys L, Day J, Cadwell B, Nemeth E: Hepcidin and iron homeostasis during pregnancy. Nutrients. 2014; 6(8):3062-83.

12. Bacchetta J, Zaritsky JJ, Sea JL, Chun RF, Lisse TS, Zavala K, Nayak A, Wesseling-Perry K, Westerman M, Hollis BW, Salusky IB, Hewison M: Suppression of iron-regulatory hepcidin by vitamin D. J Am Soc Nephrol. 2014; 25(3): 564-72.

13. Tabbah SM, Buhimschi CS, Rodewald-Millen K, Pierson CR, Bhandari V, Samuels P, Buhimschi IA: Hepcidin, an Iron Regulatory Hormone of Innate Immunity, is Differentially Expressed in Premature Fetuses with Early-Onset Neonatal Sepsis. Am J Perinatol. 2018 Feb 2. doi: 10.1055/s-0038-1626711. [Epub ahead of print]

14. Ruchala P, Nemeth E: The pathophysiology and pharmacology of hepcidin. Trends Pharmacol Sci. 2014; 35(3):15561.

15. Li S, Liu Y, Wang Y, Qi P, Wang D: The role of serum hepcidin and ferroportin1 in placenta on iron transfer from mother to fetus. Zhonghua Xue Ye Xue Za Zhi. 2015; 36(4):307-11.

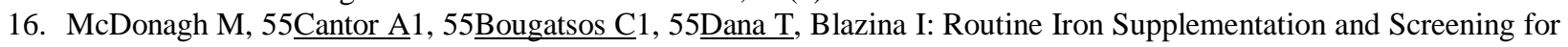
Iron Deficiency Anemia in Pregnant Women: A Systematic Review to Update the U.S. Preventive Services Task Force Recommendation [Internet]. U.S. Preventive Services Task Force Evidence Syntheses, formerly Systematic Evidence Reviews. Rockville (MD): Agency for Healthcare Research and Quality (US); 2015 Mar. Report No.: 1305187-EF-2.

17. Domellöf M, Thorsdottir I, Thorstensen K: Health effects of different dietary iron intakes: a systematic literature review for the 5th Nordic Nutrition Recommendations. Food Nutr Res. 2013, 12; 57.

18. Kinnunen TI, Luoto R, Helin A, Hemminki E: Supplemental iron intake and the risk of glucose intolerance in pregnancy: re-analysis of a randomised controlled trial in Finland. Matern Child Nutr. 2016; 12(1):74-84.

19. Harvey NC, Holroyd C, Ntani G, Javaid K, Cooper P, Moon R, Cole Z, Tinati T, Godfrey K, Dennison E, Bishop NJ, Baird J, Cooper C: Vitamin D supplementation in pregnancy: a systematic review. Health Technol Assess. 2014; 18(45):1-190.

20. Pérez-López FR, Pasupuleti V, Mezones-Holguin E, Benites-Zapata VA, Thota P, Deshpande A, Hernandez AV: Effect of vitamin D supplementation during pregnancy on maternal and neonatal outcomes: a systematic review and meta-analysis of randomized controlled trials. Fertil Steril. 2015; 103(5):1278-88

21. Stroud ML, Stilgoe S, Stott VE, Alhabian O, Salman K: Vitamin D - a review. Aust Fam Physician. 2008; 37(12):1002-5.

22. Api O, Breyman C, Çetiner M, Demir C, Ecder T: Diagnosis and treatment of iron deficiency anemia during pregnancy and the postpartum period: Iron deficiency anemia working group consensus report. Turk J Obstet Gynecol. 2015; 12(3):173-181. 
23. Andersen L, Dinesen B, Jørgensen PN, Poulsen F, Røder ME: Enzyme immunoassay for intact human insulin in serum or plasma. Clinical Chemistry, 1993; 38: 578-82.

24. Jacobs A, Warwood MJ: Ferritin in serum. Clinical and biochemical implications. N.Eng. J. Med., 1975; 292(18): 951-6.

25. Nemeth E, Tuttle MS, Powelson J, Vaughn MB, Donovan A, Ward DM, Ganz T: Hepcidin regulates cellular iron efflux by binding to ferroportin and inducing its internalization. Science, 2004; 306(5704): 2090-3.

26. Gaines-Das RE, Poole S: The international standard for interleukin-6 - evaluation in an international collaborative study. J Immunol Methods. 1993; 160: 147-53.

27. Grant CC, Stewart AW, Scragg R, Milne T, Rowden J, Ekeroma A, Wall C, Mitchell EA, Crengle S, Trenholme A, Crane J, Camargo CA Jr: Vitamin D during pregnancy and infancy and infant serum 25-hydroxyvitamin D concentration. Pediatrics. 2014; 133(1):e143-53

28. Abbas W, Adam I, Rayis DA, Hassan NG, Lutfi MF: Higher Rate of Iron Deficiency in Obese Pregnant Sudanese Women. Open Access Maced J Med Sci. 2017; 5(3):285-289.

29. Milman N, Taylor CL, Merkel J, Brannon PM: Iron status in pregnant women and women of reproductive age in Europe. Am J Clin Nutr. 2017; 106(Suppl 6):1655S-1662S.

30. Bah A, Pasricha SR, Jallow MW, Sise EA, Wegmuller R, Armitage AE, Drakesmith H, Moore SE, Prentice AM: Serum Hepcidin Concentrations Decline during Pregnancy and May Identify Iron Deficiency: Analysis of a Longitudinal Pregnancy Cohort in The Gambia. J Nutr. 2017; 147(6):1131-7.

31. Ahmed F, Khan MR, Shaheen N, Ahmed KMU, Hasan A, Chowdhury IA, Chowdhury R: Anemia and iron deficiency in rural Bangladeshi pregnant women living in areas of high and low iron in groundwater. Nutrition. 2018; 51-52:46-52.

32. Michalski ES, Nguyen PH, Gonzalez-Casanova I, Nguyen SV, Martorell R, Tangpricha V, Ramakrishnan U: Serum 25-hydroxyvitamin D but not dietary vitamin D intake is associated with hemoglobin in women of reproductive age in rural northern Vietnam. J Clin Transl Endocrinol. 2017; 8:41-8.

33. Yuan Y, Cai Z, Dai Y, Hong Q, Wang X, Zhu L, Xu P, You L, Wang X, Ji C, Wen J, Guo X: Association of Maternal Serum 25-Hydroxyvitamin D Concentrations with Risk of Gestational Anemia. Cell Physiol Biochem. 2017; 43(4):1526-32.

34. Al-Ajlan A, Al-Musharaf S, Fouda MA, Krishnaswamy S, Wani K, Aljohani NJ, Al-Serehi A, Sheshah E, Alshingetti NM, Turkistani IZ, Afrah Alharbi A, Alraqebah BA, Ali AM, Al-Saeed G, Al-Daghri NM: Lower vitamin D levels in Saudi pregnant women are associated with higher risk of developing GDM. BMC Pregnancy Childbirth. 2018; 18(1):86.

35. Krieger JP, Cabaset S, Canonica C, Christoffel L, Richard A, Schröder T, von Wattenwyl BL, Rohrmann S, Lötscher KQ: Prevalence and determinants of vitamin D deficiency in the third trimester of pregnancy: a multicentre study in Switzerland. Br J Nutr. 2018 Feb; 119(3):299-309.

36. Wheeler BJ, Taylor BJ, de Lange M, Harper MJ, Jones S, Mekhail A, Houghton LA: A Longitudinal Study of 25Hydroxy Vitamin D and Parathyroid Hormone Status throughout Pregnancy and Exclusive Lactation in New Zealand Mothers and Their Infants at $45^{\circ}$ S. Nutrients. 2018 Jan 13;10(1).

37. Akoh CC, Pressman EK, Cooper E, Queenan RA, Pillittere J, O'Brien KO: Low Vitamin D is Associated With Infections and Proinflammatory Cytokines During Pregnancy. Reprod Sci. 2018; 25(3):414-423.

38. Cutone A, Rosa L, Lepanto MS, Scotti MJ, Berlutti F, Bonaccorsi di Patti MC, Musci G, Valenti P: Lactoferrin Efficiently Counteracts the Inflammation-Induced Changes of the Iron Homeostasis System in Macrophages. Front Immunol. 2017; 8:705.

39. Rosa L, Cutone A, Lepanto MS, Paesano R, Valenti P: Lactoferrin: A Natural Glycoprotein Involved in Iron and Inflammatory Homeostasis. Int J Mol Sci. 2017;18(9).

40. Zittermann A, Jungvogel A, Prokop S, Kuhn J, Dreier J, Fuchs U, et al. Vitamin D deficiency is an independent predictor of anemia in end-stage heart failure. Clin Res Cardiol. 2011;100:781-8.

41. Ernst JB, Becker T, Kuhn J, Gummert JF, Zittermann A. Independent association of circulating Vitamin D metabolites with anemia risk in patients scheduled for cardiac surgery. PLoS One. 2015;10: e0124751.

42. Smith EM, Tangpricha V: Vitamin D and anemia: insights into an emerging association. Curr Opin Endocrinol Diabetes Obes. 2015; 22(6):432-8.

43. Sharma S, Jain R, Dabla PK: The role of 25-hydroxy Vitamin D deficiency in iron deficient children of North India. Indian J Clin Biochem. 2015; 30:313-7.

44. Thomas CE, Guillet R, Queenan RA, Cooper EM, Kent TR, Pressman EK, Vermeylen FM, Roberson MS, O'Brien $\mathrm{KO}$ : Vitamin D status is inversely associated with anemia and serum erythropoietin during pregnancy. Am J Clin Nutr. 2015; 102(5):1088-95.

45. Azizi-Soleiman F, Vafa M, Abiri B, Safavi M: Effect of iron on vitamin D metabolism: A Systemic Review. Int J Prev Med., 2016; 7: 126. 